\title{
Patent office resurrects EST debate
}

The debate in the US over whether broad patent claims to expressed sequence tags (ESTs)-randomly isolated fragments of DNA used mainly as probes to isolate functional genes-are patentable lives on, despite a court ruling last September that could have laid the issue to rest. The concern over broad EST claims is that any DNA sequence, including functional genes, that is later found to contain the EST sequence would inftinge the EST patent. This could mean that companies currently using gene sequences in clinical trials or those selling recombinant proteins could end up infringing one or more EST patents or be forced to reengineer their gene sequences and repeat years of experiments to avoid escalating damages.

Many in the biotechnology community were relieved after the US Court of Appeals for the Federal Circuit invalidated the claims to human insulin made in a University of California (UC; Berkeley, CA) patent filing. It did so because the inventors had not satisfied the "written description" requirement. They had not disclosed in the patent application the nucleotide sequence of the claimed human cDNA sequence (Nature Biotechnology 16:87, 1998). They had disclosed the full-length amino acid sequence of human insulin and a method for isolating the human cDNA, but this, the court said, was not enough. (Nature Biotechnology 15:911, 1997).

Extrapolating from this case, which was brought because Eli Lilly (Indianapolis, IN) had challenged the UC patent, many lawyers had expected that broad EST claims would not dominate full gene and protein patents. After all, they do not-and cannot-disclose the full nucleotide sequence of any genes.

However, the US Patent and Trademark Office (PTO; Washington, DC) saw things differently. On June I5, 1998, it published interim examination guidelines indicating how it proposes to apply the "written description" requirement to biotechnology inventions earlier decision (www.uspto.gov). It concluded that the Court of Appeals's ruling in the UC/Eli Lilly case did not prevent broad EST claims from issuing.

In explaining the guidelines, Associate Solicitor Scott Chambers of the PTO Solicitor's Office points out the two primary legal reasons for narrowing the scope of patent claims: "If the prior scientific literature discloses the subject matter of the invention, or if the patent fails to enable or describe the invention. Under established

Ken Chatine is a freelance writer working in San Francisco, CA. patent law, broad EST claims overcome both hurdles." EST's are considered new because the sequences have not been published before, and EST patents presumably enable and describe at least one use (eg, as DNA probes), which is all that patent law requires.

The differences that determine whether a claim satisfies the "written description" requirement under the guidelines are largely semantic. For example, according to the PTO, a claim reading, "A gene comprising EST sequence XYZ" would not satisfy the written description requirement, while a claim reading, "A nucleic acid comprising EST sequence XYZ" would. Ironically, the latter claim is broader in scope.

According to the PTO, therefore, there does not appear to be sufficient legal basis for rejecting broad EST claims. Nevertheless, given the Federal Circuit's current reluctance to uphold broad DNA patent claims, many patent practitioners agree that the court will ultimately find - or make up - a legal basis for invalidating or narrowing the scope of EST claims.

Chambers admits that broad EST patents could force those companies using gene sequences in preclinical and clinical trials that have not patented the ESTs to negotiate a license, or reengineer their gene sequences and repeat years of experiments to avoid patent infringement. Even worse, companies currently selling recombinant proteins could end up infringing one or more EST patents.

Unless the guidelines are amended-the PTO is accepting written comments from the public until September 14, 1998-they will represent a major victory for those seeking broad EST patent protection and the defeat of possibly the last line of defense for genomic companies, which hoped the issue would be resolved at the PTO instead of federal court, where a final ruling can take a decade. Until then, companies using genes risk infringement and-once EST patents begin to issue-escalating damages.

In the meantime, emerging companies may be able to avoid patent infringement. If the gene is being used for diagnostics, using a different portion of the gene that does not encompass a patented EST sequence should accomplish the same diagnostic goal while likely avoiding patent infringement. If the value of the gene is in the protein it codes, the degeneracy of the genetic code should allow companies to alter the nucleotide sequence spanning a patented EST without altering the amino-acid sequence of the protein. Until EST patents are issued though, companies do not know what nucleotide sequences to alter.

Ken Chahine

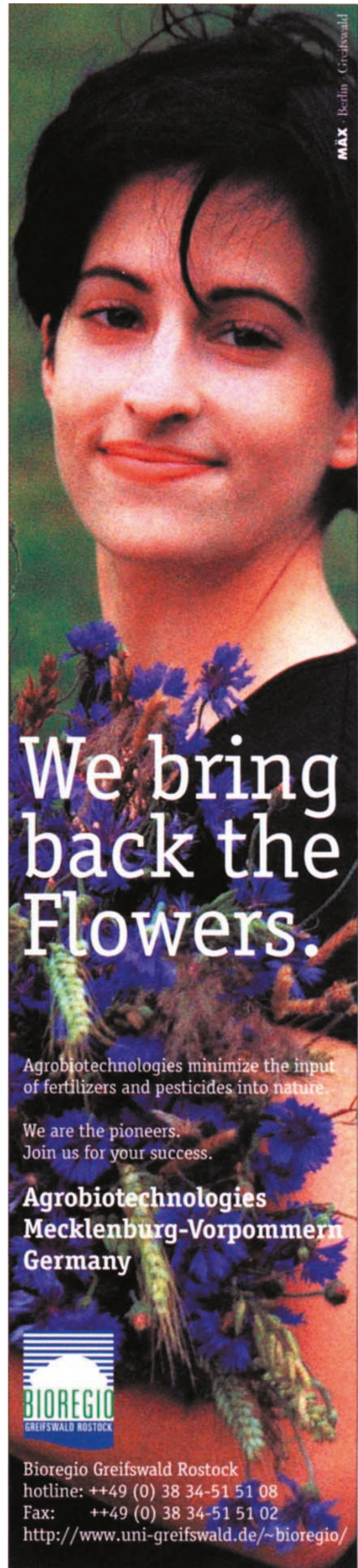

